\title{
SOB O SOL TROPICAL: O IMIGRANTE PORTUGUÊS NO RIO DE JANEIRO de Aluísio Azevedo
}

UNDER THE TROPICAL SUN: THE PORTUGUESE IMMIGRANT IN AluISIO AzEVEDO'S RIO DE JANEIRO

\author{
Mônica Figueiredo \\ Universidade Federal do Rio de Janeiro \\ Rio de Janeiro, RJ - Brasil \\ ORCID 0000-0003-2057-6894
}

\section{Resumo}

O presente trabalho pretende resgatar a obra de Aluísio Azevedo do esquecimento a que parece ter sido condenada por boa parte de nossa crítica que, desde o fim dos oitocentos, vem tratando suas narrativas como exemplos escolares de um naturalismo de segunda máo. Partindo da análise da trajetória e da composição de suas principais personagens, pretende-se averiguar como a condição do imigrante português foi recriada pelas linhas da ficção, a fim de questionar o pretenso antilusitanismo de que tantas vezes foi acusado o autor de $O$ Cortiço.

Palavras-chave: Aluísio Azevedo; naturalismo; personagem; imigrante; antilusitanismo.

\begin{abstract}
The present work intends to rescue the literary work of Aluísio Azevedo from the neglect to which it seems to have been condemned by a majority of literary critics who, since the end of the nineteenth century, have been treating his narratives as school examples of second-rate naturalism. Starting from the analysis of the evolution and the composition of his main characters, this paper seeks to find out how the condition of the Portuguese immigrant was recreated in fictional lines, in order to question the presumed anti-lusitanism
\end{abstract}

\section{Résumé}

Ce travail a pour but de récupérer l'oeuvre de Aluísio de Azevedo de l'oubli auquel il semble avoir été condamné par une bonne partie de notre critique qui, depuis la fin du XIX ${ }^{\mathrm{e}}$ siècle, s'est mise à condamner ses récits comme des exemples scolaires d'un naturalisme de seconde main. Partant de l'analyse de la trajectoire et de la composition de ses personnages les plus importants, on essaie d'examiner comment la condition de l'immigrant portugais a été recrée par les lignes de la fiction, de façon à mettre en question le prétendu antilusi- 
that the author of The Slum (O Cortiço in Portuguese) has been accused of so many times.

Keywords: Aluísio Azevedo; naturalism; character; immigrant; anti-lusitanism. tanisme dont l'auteur de $O$ Cortiço a été souvent accusé.

Mots-clés: Aluísio de Azevedo; naturalisme; personnage; immigrant; antilusitanisme.

E, no entanto, o sol, único causador de tudo aquilo.

Aluísio Azevedo, O Cortiço.

Antoine Compagnon já havia alertado que qualquer citação não é ato desprovido de vontade política, uma vez que é motivada pelo desejo daquele que cita de "pilhar" do citado a precisão de uma ideia que, náo livre de inveja, bem lhe poderia ter ocorrido! No entanto, a citação se torna ainda mais "grave" quando ganha o lugar de epígrafe, porque:

Sozinha no meio da página, a epígrafe representa o livro - apresenta-se como seu senso ou seu contrassenso -, infere-o, resume-o. Mas, antes de tudo, ela é um grito, uma palavra inicial, um limpar de garganta antes de começar realmente a falar, um prelúdio ou uma confissão de fé: eis aqui a única proposição que manterei como premissa, não preciso de mais nada para me lançar. Base sobre a qual repousa o livro, a epígrafe é uma extremidade, uma rampa, um trampolim, no extremo oposto do primeiro texto, plataforma sobre qual o comentário ergue seus pilares. (COMPAGNON, 1996, p. 80)

Uso, pois, um trecho do romance como "trampolim" para repensar algumas - das muitas! - assertivas que se cristalizaram como leitura definitiva para $O$ Cortiço, de Aluísio Azevedo. No entanto, é preciso que se tenha em vista que minha epígrafe está aqui mais a serviço do "contrassenso" do que do "senso"; ou, por outras palavras, quero que fique claro que ela surge como um duplo trabalho de "pilhagem": primeiro, tomada do romance publicado em 1890, e depois retirada de inúmeros textos críticos que, invariavelmente, recuperam esta passagem para dar conta das terríveis condiçóes climáticas a 
que estavam submetidas as personagens de uma narrativa que, para muitos ensaístas, depositou nos rigores de uma natureza inclemente a explicação para o descompasso de suas criaturas de papel, provando assim a inquestionável subserviência da ficção de Aluísio Azevedo aos ditames cientificistas do "romance experimental" preconizado por Zola. Contrariando as ideias de Antônio Candido, que igualmente se apropria do mesmo trecho do romance (usando-o em seu "De cortiço a cortiço" (1998), ensaio onde defende que tanto o "Carapicus" quanto o "Cabeça de Gato", bem como o novo "Avenida São Romão" são, a seu modo, representaçôes do espaço nacional), Paulo Franchetti resume de maneira exemplar o uso que se fez de minha já agora epígrafe:

O alcance de $O$ Cortiço, assim, aparece bem reduzido em relaçáo ao esforço de Candido de dotá-lo de um forte sentido nacional. E ele se deixa mais facilmente ler como aquilo que parece de fato ser: um romance de carregado estilo naturalista, no qual a força determinante na conformaçáo e destino dos personagens não é tanto o meio social ou os caracteres herdados, mas o ambiente natural, isto é, o clima dos trópicos, regido pelo sol escaldante, que o narrador textualmente afirma, ao narrar a guerra entre os miseráveis, tratar-se do "único causador de tudo aquilo". (FRANCHETTI, 2011, p. 94)

Antes de problematizar o determinismo nefasto com que o sol dos trópicos seria, ou não, capaz de aprisionar o destino das personagens, gostaria de começar por lembrar - através de inevitável digressão - que uma epígrafe como esta jamais seria "prelúdio", "premissa", "base", ou "palavra inicial" de uma reflexão que não se debruçasse sobre a literatura produzida depois das reflexóes de Rousseau. O mesmo Paulo Franchetti, partindo das reflexóes de Gustave Lanson, adverte que foi o pensamento rousseauniano que trouxe o fora para dentro da literatura da Europa de então, transformando a

1 A história centra-se no cotidiano do cortiço Carapicus que, destruído por um incêndio, é reerguido pelo seu dono, já agora em franca fase de aburguesamento, ostentando indisfarçáveis melhorias que reafirmavam o processo de refinamento a que João Romão se dedicara com afinco canino. O Cabeça de Gato, antigo concorrente, passa a ser o destino possível para aqueles que já não mais cabiam no novo Avenida São Romão, firmando-se como um depósito para os mais socialmente rejeitados. 
natureza em objeto de estudo e de expressão. Contrabandeando aqui a tradução feita por Franchetti, aproprio-me da reflexão de Lanson, sem deixar de concordar com o tradutor quando este desconfia de certo exagero - de clara dicção oitocentista -, cometido pelo crítico francês no afã de afirmar a singularidade da obra de Rousseau:

[...] antes de Rousseau, a natureza não tinha lugar na literatura. Ele a transforma em soberana: ela se torna objeto de estudo e de expressáo. É o sinal de uma grave mudança: terminou a literatura psicológica. Enquanto apenas o homem era assunto do livro, ele era visto por dentro: agora a natureza divide com ele a atenção do escritor, e daí resulta que, tomando-o com a natureza, ele é visto dentro da natureza, isto é: por fora. A literatura será então pitoresca, mais do que psicológica: mesmo para descrever a alma, ela olhará o corpo. Rousseau vê Júlia loira e Clara morena; mudando a cor dos cabelos dessas mulheres toda a composição do romance se embaça. ${ }^{2}$ (FRANCHETTI, 2013)

Em verdade, o Romantismo que surge na avalanche iluminista e revolucionária do século XVIII não vai voltar as costas para a "literatura psicológica", como exageradamente pretendeu Gustave Lanson. Paralelo ao apelo ao subjetivismo, é certo que a literatura romântica irá valorizar o espaço de sobremaneira, tornando-o, não raras vezes, um elemento estruturador de sua narrativa e um motivo precipitador da aventura lírica, vivida pela poesia dos últimos anos dos setecentos e estendida para além da metade dos oitocentos. Se concordarmos com a já clássica reflexão feita por Antônio Candido (1981), no que diz respeito ao início de uma literatura nacional no Brasil, consideraremos o Romantismo a nossa primeira dicção literária. Para o crítico, mais livre das influências estrangeiras e à procura de um discurso que construísse esteticamente uma identidade para a então “jovem” nação, os nossos artistas românticos, mais especificamente os prosadores, deram especial atenção à "descrição dos tipos humanos e formas de vida social nas cidades e nos campos”, característica que leva

2 Segundo indicação de Paulo Franchetti, o trecho traduzido é "Gustave Lanson. Histoire de la littérature française. Paris: Librairie Hachette, s/d, p. 802, tradução minha” (FRANCHETTI, 2013). 
o ensaísta a defender que o "romance brasileiro nasceu regionalista e de costumes” (CANDIDO, 1981, p. 113).

$\mathrm{O}$ que para esta reflexão interessa é o fato de Antônio Candido entender que o dito regionalismo "[...] nasceu em parte como fruto da dificuldade de desdobrar a sociedade urbana em temário variado para o romancista" (CANDIDO, 1981, p. 126), uma vez que a sua ainda precária fisionomia citadina não permitia as variaçóes de tempo e de espaço como, em comparação, uma França secular voluptuosamente se oferecia à pena de Balzac. Se a cidade brasileira não era a urbe francesa de Sthendal, ou a inglesa de Jane Austen, é certo que ainda assim conseguiu gerar ficção que, de um Memórias de um sargento de milícias aos perfis femininos de José de Alencar, acabou por enfrentar o cerco da ambientaçáo rural, abrindo caminho para que a prosa realista-naturalista erguesse o Rio de Janeiro do fim do Segundo Império e o dos primeiros anos da Primeira República. Mais campo ou menos cidade, Antônio Candido foi categórico ao afirmar que:

Por isso mesmo, o nosso romance tem fome de espaço e uma ânsia topográfica de apalpar todo o país. Talvez o seu legado consista menos em tipos, personagens e peripécias do que em certas regióes tornadas literárias, a sequência narrativa inserindo-se no ambiente, quase se escravizando a ele. Assim, o que se vai formando e permanecendo na imaginação do leitor é um Brasil colorido e multiforme, que a criação artística sobrepóe à realidade geográfica e social. Esta vocação ecológica se manifesta por uma conquista progressiva de território. (CANDIDO, 1981, p. 114)

Náo posso negar que a ideia de que "nosso romance tem fome de espaço" me seduz e chego mesmo a concordar com ela, embora aportada num raciocínio que, de certa forma, vai na contramão do que na sequência Antônio Candido acaba por defender, ou seja, que nossos "tipos, personagens e peripécias" não estabeleçam um "legado", pois estariam "escravizados" a uma emergência de espaço avassaladora. A meu ver, e seguindo outro ensinamento do ensaísta, "o enredo existe através das personagens; as personagens vivem no enredo. Enredo e personagem exprimem, ligados, os intuitos do 
romance, a visão da vida que decorre, os significados e valores que o animam" (CANDIDO, 2004, p. 53-54). Se o intuito de nossa ficção em prosa foi dar vez a uma "ânsia topográfica de apalpar todo o país", ela só se concretizou porque esteve emblematicamente misturada na cor e cheiro de Gabriela; no corpo virginal de Iracema; na feiura descarada e multiétnica de Macunaíma; na dubiedade sertaneja, brutal e desejosa de Riobaldo e de Diadorim; na miséria agreste de Fabiano e de Sinhá Vitória; nos citadinos olhos de ressaca de Capitu; ou ainda na existência anacrônica, desprotegida e retirante de Macabéa. Por outras palavras, é nas personagens do romance brasileiro que nossa topografia melhor se inscreveu e garantiu, para fora das páginas dos livros, a perenidade.

Sabedora da extensão que tomou esta digressão, volto agora a $O$ Cortiço e à minha já quase esquecida epígrafe, retomando-a para tentar desestabilizar algumas "certezas" sobre um romance que, a priori, se prestou muito facilmente a exemplo da tal fome topográfica defendida por Antônio Candido. De fato, o espaço parece ser mesmo o grande protagonista, e muitas foram as leituras que defenderam esse ponto de vista, exaltando seus aspectos descritivos marcados por um tom naturalista, que condicionariam as personagens-tipo a um anônimo segundo plano. Muitas destas interpretaçôes - e aqui me valho da de Paulo Franquetti - insistem na presença avassaladora e corrosiva de um sol que condenaria à animalidade os moradores do cortiço: "E, no entanto, o sol, único causador de tudo aquilo". A frase aparece inclusa na narração da briga que pôs em lados opostos os moradores do cortiço de João Romão e os do Cabeça de Gato, graças à morte de um dos seus, o capoeira Firmo, assassinado pelo português Jerônimo, mestre da pedreira de Romão. Separado do contexto, o trecho realmente parece acusar o sol - e toda a realidade tropical que ele encerra - da responsabilidade pela ferocidade de homens e mulheres que lutam numa batalha campal. No entanto, se lido dentro do parágrafo que o abriga, acho que fica impossível manter exclusivamente a negatividade defendida por tantos críticos que dela se valeram para apontar a nota naturalista que acompanharia a descrição da realidade espacial que cercava os moradores. Vejamos:

Os Carapicus enchiam a metade do cortiço. Um silêncio arquejado sucedia à estrepitosa vozeria do rolo que 
findara. Sentia-se o hausto impaciente da ferocidade que atirava aqueles dois bandos de capoeiras um contra o outro. E, no entanto, o Sol, único causador de tudo aquilo, desaparecia de todos nos limbos do horizonte, indiferente, deixando atrás de si as melancolias do crepúsculo, que é a saudade da terra quando ele se ausenta, levando consigo a alegria da luz e do calor. (AZEVEDO, 2011, p. 212)

O sol de fato só surgirá em negativo, quando for recuperado pelas descriçóes que denunciam a precariedade das condiçóes a que estavam submetidas as personagens, na sua maioria trabalhadores explorados que viviam sob o jugo da mais-valia, num país de herança escravocrata que tacanhamente engatinhava o seu aburguesamento. Em parte, adiantando o que o Romance de 30 do século XX (ou Regionalista, para quem assim o preferir) iria transformar em proposta - primeiro ideológica, e depois estética -, o narrador de Aluísio Azevedo desvela, através de um discurso artisticamente acurado, a demanda do homem com espaço, tornando os corpos de seus personagens - e a "topografia" social que eles encerram - em lugar de problematização histórica, salvando-os, a meu ver, do estrito lugar de "peça" de um exercício "experimental", como quis certo naturalismo empedernido ${ }^{3}$, bem como boa parte da crítica que despendeu esforços no sentido de aí alocar a obra de Aluísio Azevedo. Como nem tudo cabe nas "gavetas", a capacidade estética do autor de $O$ Cortiço retira

3 Lucidamente, Leonardo Mendes problematiza os rigores de certa vertente naturalista: "A relação entre o Naturalismo e a ciência é mais problemática do que o ensaio "O romance experimental” dá a entender, mas a centralidade do texto na construção dos esquemas de compreensão do romance naturalista contribuiu para que ele fosse colocado inteiro na esfera política do que Alain Touraine chama de "modernidade triunfante". O termo descreve a modernidade como uma epopeia da razão que conduz inexoravelmente as sociedades ao aperfeiçoamento civilizatório. Se a civilização moderna é um processo inelutável e libertador, em nome dela se justificam até mesmo as pretensóes imperialistas que a Europa nutriu e implementou naqueles mesmos anos em que Zola escrevia romances científicos. O romance naturalista teria participado do grande empreendimento expansivo, depredador e autoritário que foi a civilização moderna da segunda metade do século XIX. Sem muito esforço, o médico-romancista se transforma num colonizador de corpos, sejam eles os corpos das mulheres, das prostitutas, dos pobres ou dos "pervertidos", todos aqueles que habitavam as cozinhas da sociedade. Como tal, o romance naturalista é compreendido como um discurso empenhado no abafamento de conflitos sociais e na instituição de normas, verdades identitárias, racismos e violências. É possível que este enquadramento crítico não faça justiça ao romance naturalista francês" (2013, p. 17). 
o sol da previsível função "tropicalmente" determinista ${ }^{4}$, ilumina seus personagens, pondo-os em luta contra uma realidade social, que é, esta sim, a verdadeira vilá, e não qualquer forma de representação da natureza - seja humana ou não - , pois não raras vezes se encontram unidas numa mesma cadeia de sofrimento e de exploração:

Aqui, ali, por toda parte, encontravam-se trabalhadores, uns ao sol, outros debaixo de pequenas barracas feitas de lona ou de folhas de palmeira. De um lado cunhavam pedra cantando; de outro a quebravam a picareta; de outro afeiçoavam lajedos a ponta de picão; mais adiante faziam paralelepípedos a escopro e maceta. E todo aquele retintim de ferramentas, e o martelar da forja e o couro dos que lá em cima brocavam a rocha para lançar-lhe fogo, e a surda zoada ao longe, que vinha do cortiço como de uma aldeia alarmada; tudo dava a ideia de uma atividade feroz, de uma luta de vingança e de ódio. Aqueles homens gotejantes de suor, bêbados de calor, desvairados de insolaçáo, a quebrarem, a espicaçarem, a torturarem a pedra, pareciam um punhado de demônios revoltados na sua impotência contra o impassível gigante que os contemplava com desprezo, imperturbável a todos os tiros que lhe desfechavam no dorso, deixando sem um gemido que lhe abrissem as entranhas de granito. (AZEVEDO, 2011, p. 58)

Encaminho meu raciocínio, portanto, na contramão do que afirma Alfredo Bosi (1994, p. 190) sobre Aluísio Azevedo, para ele um autor que "[se] ateve à sequência de descriçóes muito precisas onde cenas coletivas e tipos psicologicamente primários fazem, no conjunto, do cortiço a personagem mais convincente do nosso romance naturalista”. Obviamente, não estou questionando a importância do espaço dentro da narrativa e em nada me incomoda o aclamado protagonismo dado ao Carapicus; mas, antes, o que gostaria

4 Affonso Romano de Sant'anna, igualmente, defende a inevitabilidade determinista provocada pelo sol, utilizando o mesmo trecho do romance como exemplo: "Definidos totemicamente com suas bandeiras os grupos se aproximam com suas armas (navalhas) e com suas músicas (dança dos capoeiras). Tem início o torneio, que culmina com o incêndio desencadeado pela Bruxa - sempre envolvida com o fogo. E para explicar a gênese do confronto, surge o narrador reafirmando a ideologia naturalista e servindo-se dos modelos da série científica: "E, no entanto, o sol, único causador de tudo aquilo" (1973, p. 115-116). 
de problematizar são assertivas como "Existe o quadro: dele derivam as figuras" (BOSI, 1994, p. 190), que a meu ver parecem esquecer que são primeiro estas figuras que, através de suas existências, sustentam a arquitetura do enredo, dando ao espaço a verossimilhança necessária para que chegue mesmo, aos olhos de muitos leitores, a ganhar o lugar de protagonista. Por outras palavras, é na topografia do corpo de Rita Baiana, de Jerônimo, de João Romão, de Bertoleza, enfim, é na existência referencialmente histórica das personagens - todas habitantes da "cozinha social"s do Brasil do fim do Segundo Império e dos primeiros anos da Primeira República ${ }^{6}$ - que esta ficção se concretiza. Com permissão para a ousadia, corrijo Bosi: existem as figuras: delas derivam o quadro!

Carlos Reis (2015, p. 89) já havia advertido que “[...] são as personagens e os lugares que formam os referentes primários da narrativa literária”, raciocínio que em muito encontra eco nos estudos da mais atual geografia cultural que igualmente entende o lugar como uma circunstância espacial em demanda com o humano, junção que afinal acaba por defini-lo como uma dimensão humanizada por excelência. Ainda que se tratando de uma "outra forma de geografia", fica claro, portanto, que os lugares da ficção mantêm estreita dependência da personagem, ao mesmo tempo que ratificam uma profunda e irrompível ligação com o mundo real e com o conhecimento que dele temos. Esquecer disso significaria dar azo à "[...] radicalização da autonomia que [mundos possíveis ficcionais] reclamam - mesmo quando parecem apontar nesse sentido", e defender uma "[...] absurda concepção dos textos ficcionais como textos autotélicos e desligados do mundo" (REIS, 2015, p. 78).

Gostaria de pensar agora a geografia imposta pelo corpo de Rita Baiana, ou antes quereria problematizar o "mundo possível" fatalmente alegórico, porque antes de tudo literário - erguido pelos passos sensuais de uma personagem que parece inebriar e seduzir a

5 Parto da definição de Leonardo Mendes (2013, p. 17), citada na nota 3.

6 Ao apresentar o projeto ficcional "Brasileiros antigos e modernos" - em A Semana de 31/10/1885 -, Aluísio Azevedo afirmava pretender escrever cinco romances (entre eles $\mathrm{O}$ Cortiço) que abarcassem "a sociedade brasileira do Império desde o seu nascimento até a sua ruína que ele sentia próxima”. Planejava o autor reunir ali "todos os tipos brasileiros, bons e maus, do seu tempo e compendiar em forma de romance, todos os fatos de nossa vida pública, que jamais serão apresentados pela História” (MÉRIEN, 2013, p. 504). 
realidade quase sempre grotesca que tem à sua volta. É claro que a percepção alegórica da fisicalidade desta personagem não passou despercebida de grande parte da crítica que a viu sempre plena "de fora", marcada pela paisagem brasileira, uma espécie de atlas geográfico de exuberante exterioridade, que redundava num exemplo de vazio subjetivo. Dentre essas leituras, destaco a feita por Luiz Dantas (1990), que magistralmente a separa da Naná de Zola (Naná de 1880), por entender que a personagem francesa é muito mais generalizante do que se pode à primeira vista imaginar, uma vez que encarna a alma e o destino da mulher pobre, emparedada em meio à cidade burguesa, afastada - por sua origem social - da cultuada civilidade da Europa oitocentista, presa à bestialidade dos instintos, firmando-se como representante de um exotismo social que afinal engloba aquilo que vulgarmente era chamado de povo! $\mathrm{Na}$ contramáo da protagonista oriunda da referencialidade histórica da França de Napoleão III, Luiz Dantas defende:

Ao lado de Naná, a personagem de Rita Baiana, a Iracema mestiça, moderna, urbana e anti-romântica [sic] de Aluísio Azevedo, se delineia de forma mais completa. O seu erotismo dissolvente, secretado pela paisagem esplendorosa, atributo de seu exotismo, é reforçado e agravado por ela ser igualmente um produto da miséria. Ela está duplamente distante. Atavismo impossível de exorcizar, se o país é sensual pela própria natureza e se a sensualidade é um atributo da pobreza, o Brasil erótico é consequentemente o Brasil miserável. (DANTAS, 1990, p. 465)

O exotismo geográfico encarnado por Rita Baiana ganha, assim, uma outra perspectiva: ela é a terra selvagem, a memória de um Brasil pobre mas incontrolável, que faz frente ao modelo burguês imposto pelo neocolonialismo que aqui chegava de segunda mão, com fisionomia agrária, latifundiária, escravocrata, clientelista, coronelista, e marcado por uma política "de arranjos". Rita Baiana é, ao fim e ao cabo, uma forma arcaica, uma mulher-floresta que destoava do programa civilizador que, não sem custo, quis redesenhar um Rio de Janeiro inspirado no projeto modernizador de sociedade urbana, erguido modelarmente pela França do Barão de Haussmann (1853- 
1870). Na clássica cena em que Jerônimo vê a mulata dançar pela primeira vez e antes mesmo do português gozar com a visão do "paraíso", o narrador deixa claro que é o próprio "paraíso" que tem imenso prazer de assim o ser; afinal, Rita dança "numa sofreguidão de gozo carnal num requebrado luxurioso que a punha ofegante", arrastando "a todos, despoticamente, desesperando aos que não sabiam dançar" (AZEVEDO, 2011, p. 89), pois:

Naquela mulata estava o grande mistério, a síntese das impressóes que ele [Jerônimo] recebeu chegando aqui: ela era a luz ardente do meio-dia; ela era o calor vermelho das sestas da fazenda; era o aroma quente dos trevos e das baunilhas, que o atordoara nas matas brasileiras; era a palmeira virginal e esquiva que se não torce a nenhuma outra planta; era o veneno e era o açúcar gostoso; era o sapoti mais doce que o mel e era a castanha do caju que abre as feridas com seu azeite de fogo; ela era a cobra verde e traiçoeira, a lagarta viscosa, a muriçoca doida, que esvoaçava havia muito tempo em torno do corpo dele, assanhando-lhe os desejos, acordando-lhe as fibras embambecidas pela saudade da terra, piscando-lhe as artérias, para lhe cuspir dentro do sangue uma centelha daquele amor setentrional, uma larva daquela nuvem de cantáridas que zumbiam em torno da Rita Baiana e espalhavam-se pelo ar numa fosforescência afrodisíaca. (AZEVEDO, 2011, p. 90)

Rita Baiana, "a palmeira virginal e esquiva que se não torce a nenhuma outra planta”, parece que foi capaz de seduzir até seu criador, porque só isso explica o exercício do dispêndio provocado na narrativa que se alvoroça numa dicção que foge do tom científico, da dureza do registro e da elucubraçáo racional toda vez que tem de abrir lugar para abrigar a presença desta personagem. É Rita quem mais facilmente leva o narrador a perder o desejado distanciamento crítico, e provoca um excesso descritivo - uma verdadeira orgia imagística - que rompe com o sentido documental do relato para, sem pudor, atacar sensoriamente o corpo de uma personagem que cheira e sabe bem, ao mesmo tempo em que preenche os olhos do leitor que não se pode furtar a devorar um corpo de papel que se oferece táo lexicalmente! Estamos diante de uma personagem de duplo poder: 
com seu corpo vivo no enunciado seduz Jerônimo e a todos por onde passa; com sua presença inscrita pela enunciação, ataranta os olhos e a imaginação do leitor desavisado há mais de um século!

No entanto, é preciso lembrar de que nem todas as personagens femininas estão marcadas por esta exuberância indomável que, se ainda não é capaz de vencer o status quo, também não é vencida, resistindo na sua diferença dentro de um romance em que nada, ou quase nada, parece ficar no mesmo lugar, apesar da imutabilidade das forças que representam o poder constituído. De fato, assistimos apenas ao troca-troca de lugares que mostra que, para cada novo habitante da ascensional "Avenida São Romáo", uma infinidade anônima de moradores toma de assalto as vielas do "Cabeça de Gato", deixando claro que o mundo da miséria pode ser "naturalmente" reconstituído. Digo "naturalmente" porque recupero a ideia de Affonso Romano de Sant'anna (1973) que defendia que $O$ Cortiço deveria ser lido a partir de um eixo interpretativo que privilegiasse o enfrentamento entre os valores que representavam a "natureza" $\mathrm{X}$ e os que representavam a "cultura". Para o crítico, João Romão encarnaria esta força natural (porque bruta), que palmo a palmo disputaria com o aculturado, (porque aburguesado) Miranda, a posse de uma terra que, em verdade, não pertencia a nenhum dos dois. Confesso que me custa um pouco ver Miranda como representante confortável de uma burguesia que, originariamente imigrante, conseguiu enriquecer e prosperar através do trabalho duro, já que, no caso dele, teve de casar com uma brasileira que lhe cobria de vergonha, ao lhe acinzentar a virilidade e a honra, conduta que a sociedade de entáo náo costumava perdoar facilmente. A meu ver, Miranda - guardadas as devidas proporçóes - casou-se com uma também "palmeira esquiva que se não torce a nenhuma outra planta" e com ela selou seu destino, transformando a promessa de enriquecimento através de um casamento de conveniências numa "áfrica" nunca efetivamente conquistada, firmando-se como mais um “jerônimo” traído pelo corpo-terra brasileira:

Mas então, ele Miranda, que se supunha a última expressão da ladinagem e da esperteza; ele, que, logo depois do seu casamento, respondendo para Portugal a um ex-colega que o felicitava, dissera que o Brasil era uma cavalgadura carregada de dinheiro, cujas rédeas um homem 
fino empolgava facilmente; ele, que se tinha na conta de invencível matreiro, năo passava afinal de um pedaço de asno comparado com o seu vizinho! Pensara fazer-se senhor do Brasil e fizera-se escravo de uma brasileira mal-educada e sem escrúpulos de virtude! Imaginara-se talhado para Grandes conquistas, e náo passava de uma vítima ridícula e sofredora! .... Sim! No fim de contas qual fora a sua áfrica? .... Enriquecera um pouco, é verdade, mas como? A que preço? Hipotecando-se a um diabo, que lhe trouxera oitenta contos de réis, mas incalculáveis milhóes de desgostos e vergonhas? [...] Qual era afinal a sua grande existência? Do inferno da casa para o purgatório do trabalho e vice-versa! Invejável sorte, não havia dúvida! (AZEVEDO, 2011, p. 31)

Será ainda neste mesmo ensaio que Affonso Romano de Sant'anna (1973) levantará uma outra hipótese, a que recorro para em seguida desenvolver um outro raciocínio. Neste livro, as mulheres funcionariam como elementos de troca que facultariam a mobilidade do masculino - mais especificamente de Joáo Romão - do espaço da "natureza" para o espaço da "cultura". O crítico usa como exemplos emblemáticos Zulmira e Bertoleza, espécies de moeda gastas na ascensão social do imigrante português que as tantas se cansa de "ter vivido como vivera até ali, curtindo privaçóes, em tamancos e mangas de camisa" (AZEVEDO, 2011, p. 133), e decide, sob o corpo da escrava que até ali explorara e de olho no corpo da vizinha que lhe serviria de passaporte para chegar à Rua do Ouvidor, modificar-se:

Por que se não habituara com as roupas finas, e com o calçado justo e com a bengala, e com o lenço [...] e com tudo que os outros usavam naturalmente sem precisar de privilégio para isso? ... Maldita economia! - Teria gasto mais, é verdade! .... Não estaria tão bem! ... mas, ora adeus! Estaria habilitado a fazer do meu dinheiro o que bem quisesse! .... Seria um homem civilizado! ... (AZEVEDO, 2011, p. 134).

Bertoleza é sintomaticamente construída no avesso de Rita Baiana. Ela é o Brasil que tem de morrer e morre porque, para a sua condição de utensílio necessário ao enriquecimento alheio joga- 
do fora no momento em que perde a sua serventia, a morte é, sem dúvida, uma opçáo melhor do que a vida. O discurso abolicionista incide sub-repticiamente na cena violenta que encerra o livro: como uma cusparada disparada na direção do leitor "de bem", Bertoleza, a escrava espoliada e enganada pelo amo a quem serviu como quem serve "a seu homem", encontra a morte usando a mesma faca com que construiu a riqueza do explorador que veio de fora e que sistematicamente dilapidou a escravizada terra brasileira: "À medida que ele galgava posição social, a desgraçada fazia-se mais e mais escrava e rastreira. João Romão subia e ela ficava lá embaixo, abandonada como uma cavalgadura de que já não precisamos para continuar a viagem" (AZEVEDO, 2011, p. 165). Levantando o véu da hipocrisia burguesa, Aluísio Azevedo termina seu romance sem punir a infâmia que norteou os passos de muito de suas personagens, criando "uma polemica e faz[endo] com que os leitores dos bairros ricos do Rio de Janeiro descobrissem quais eram as bases da sociedade na qual viviam"(MÉRIEN, 2013, p. 526).

A dureza que reveste o fim da narrativa espelha a crueza do tempo referencialmente histórico, tempo que encenava nos trópicos um neocolonialismo de segunda mão, que rapidamente transformou a jovem Primeira República num exemplo de território onde o enriquecimento ainda acontecia graças à escravização do trabalho alheio e à espoliação sem critérios dos recursos naturais, não sendo gratuito que tanto Bertoleza quanto a pedreira sejam as sombras que protegem o enriquecimento especulativo de João Romão. Se os antigos colonizadores agora eram imigrantes empobrecidos que, como seus antepassados, igualmente buscavam o sonho da riqueza na terra "em [que] se plantando tudo dá", a verdade é que, na segunda metade dos oitocentos, a presença lusa não era mais tolerada de forma obediente ou pacífica, pois o antilusitanismo já era então a resposta brasileira à rechaçada presença portuguesa, não apenas nos quadros políticos do tempo, mas principalmente no comércio varejista, que movimentava a economia das principais cidades da recente República. Para os brasileiros:

Portugueses eram marinheiros, eram puças, eram pés-de-chumbo, termo este que designava, essencialmente, os soldados das Divisóes Auxiliadoras Portuguesas [...]. 
Finalmente, também o perfil do imigrante português funcionou como incentivo ao antilusitanismo [...]. Tal processo gerou consequências que reforçaram o estereótipo negativo do imigrante português, especialmente aos olhos das elites: não era este o imigrante com o qual elas sonhavam para a construçáo de um Brasil europeizado e, de preferência, próximo a um ideal ariano. E, por outro lado, era um concorrente para o brasileiro pobre, que precisava espremer-se para caber em uma ordem escravista e que teve que enfrentar a concorrência lusitana após a abolição. (SOUZA, 2005, p. 143)

Assim, sempre me pareceu estranho a "acusação" que sobre este romance recaiu: a de que ele defendia a superioridade portuguesa, argumento levado a cabo por parte da crítica ao privilegiar a escolha de suposto "branqueamento" feita por Rita Baiana, ao trocar Jerônimo por Firmo; e por Bertoleza, ao se ligar a João Romão. Leonardo Mendes lucidamente recorda ser já impossível naquele momento falar-se de exaltação "colonialista", visto que o antilusitanismo era uma realidade histórica com que a obra de Aluísio Azevedo de perto mantinha estreito diálogo:

Em $O$ Cortiço, um comentário do narrador no capítulo $\mathrm{XV}$ - o de que a mulata Rita Baiana teria escolhido o português Jerônimo como parceiro por ser ele de uma "raça superior" - é inflacionado pela crítica a ponto de obliterar completamente o desprezo com que o narrador trata todos os portugueses (incluindo o vilāo João Romão) na economia do romance. Isso se verifica não só aqui, mas também em $O$ Mulato, e em escritos esparsos como "Casas de Cômodos", no qual os portugueses proprietários de quartos para alugar aparecem como "malandros" que viviam da exploração da miséria de brasileiros desvalidos, entre os quais se encontravam os poetas boêmios. No contexto político do início da República, a xenofobia antilusitana faria piada de qualquer teoria de superioridade racial do português. (MENDES, 2013, p. 18)

Leonardo Mendes defende que o romance de Aluísio Azevedo flagra "as vozes da cozinha" no Brasil do fim da Monarquia e do início da República, apontando a circularidade do enredo como um 
sinal que coloca em "suspeição a possibilidade do progresso, da justiça e da verdade - tudo aquilo que almejava o método experimental" (MENDES, 2013, p. 19), criando com isso um naturalismo à brasileira, "uma autêntica antiepopeia [sic] do mesquinho e do banal, com heróis ambíguos, fechada sobre si mesma” (MENDES, 2013, p. 20). Repito que a ideia das "vozes da cozinha" em muito me seduz, de tal maneira que, para mim, mais do que um romance naturalista, Aluísio Azevedo acaba por escrever uma narrativa que anuncia aquilo que o futuro Romance de 30 no Brasil e o neorrealismo português irão transformar em projeto estético, projeto este que, convenhamos, usou e abusou da dicção naturalista no que ela tinha de melhor a oferecer!

$\mathrm{O}$ que não se pode de fato perpetuar é a leitura equivocada que insistiu em defender a apologia feita pelo autor de $O$ Cortiço em relação à suposta superioridade da figura do imigrante português sob a horda de outros tantos desgraçados. O que há no livro é uma ironia desencantada que denuncia a luta por pequenos poderes num mundo pleno de desvalidos, sejam eles burgueses medianos que casam por interesse e vivem às expensas dos caprichos da verdadeira dona da casa; sejam burros de carga, avarentos e mesquinhos, que fazem tudo e mais alguma coisa em nome do enriquecer; sejam ainda aqueles que, fracos de valores e de espírito, não são capazes de resistir à tentação libertária que se personifica num corpo de mulher. Assim, é preciso não esquecer que a inveja, a cobiça ou o desejo que estes personagens despertam só são possíveis naqueles que, como eles, sofrem aprisionados na "cozinha social" do Rio de Janeiro da segunda metade do século XIX. Neste sentido, torna-se previsível o olhar despeitado que João Romão lança sobre Miranda; a cobiça financeira de Miranda sobre a prosperidade visível da "besta" de trabalho que lhe parecia o vizinho; a inevitável e necessária "associação de cama e mesa” firmada por Bertoleza com João Romáo; e a desejosa vontade de Rita Baiana em se destacar através do enlace com um português - uma espécie em diferença -, capaz de ratificar o poder de sedução que a distinguia socialmente em meio a uma anônima multidão. Se revistos com cuidado, não há, em nenhum dos casos, a hipótese de superioridade rácica ou ética do português como grande parte da crítica preferiu entender. $\mathrm{Na}$ verdade, o imigrante é visto como veículo/instrumento 
capaz de garantir a melhoria, a liberdade, o prazer ou o repouso para corpos irremediavelmente presos num espaço opressor.

Com este romance, Aluísio Azevedo profeticamente anuncia o fim de uma cidade posta abaixo nos primeiros anos do século XX através da política draconiana do governo de Pereira Passos que, com seu processo de "higienização", varreu para o cume das recentes favelas a "sujidade" represada nos antigos cortiços. Voltando ao início destas consideraçóes, considero que este livro encena de maneira enviesada a "fome de espaço" apontada por Antônio Candido, já que ela está presente tanto no nível da enunciação, como no nível do enunciado. Se o narrador parecer ter verdadeira predileção pelas descriçóes que recuperam a paisagem que serve de cenário "organicamente vivo" ao seu enredo, as personagens de $O$ Cortiço estão igualmente marcadas por uma obsessão espacial que as faz desejar ora a evasáo, ora a ultrapassagem - seja metafórica ou concreta - de um "lugar" histórico-social que, mais que o sol, era sim, a meu ver, o "único causador de tudo aquilo".

\section{Referências bibliográficas}

ABREU, Maurício de Almeida. Da habitação ao habitát: a questão da habitação no Rio de Janeiro e a sua evolução. Revista Rio de Janeiro, n. 10, p. 210-234, 2003.

AZEVEDO, Aluísio. O Cortiço. Rio de Janeiro: Nova Fronteira, 2011.

BOSI, Alfredo. História Concisa da Literatura Brasileira. São Paulo: Cultrix, 1994.

CANDIDO, Antônio. De cortiço a cortiço. In: $O$ discurso e a cidade. São Paulo: Livraria Duas Cidades, 1998, p. 123-153.

. A personagem do romance. In: Paulo: Perspectiva, 2004, p. 53-80. . A personagem de ficção. São

. Formação da Literatura Brasileira: (momentos decisivos), v. 1 e 2. Belo Horizonte: Editora Itatiaia, 1981.

COMPAGNON, Antoine. O trabalho da citação. Belo Horizonte: Editora UFMG, 1996.

DANTAS, Luiz. As armadilhas do paraíso. In: NOVAES, Adauto. O Desejo. São Paulo: Companhia das Letras, 1990, p. 457-470. 
ENDERS, Armelle. A história do Rio de Janeiro. Rio de Janeiro: Gryphus, 2015.

ENGEL, Magali Gouveia. Onde moram os pobres? Representaçóes literárias das habitaçôes populares (Rio de Janeiro, fins do século XIX e inicios do XX). Revista do Arquivo Geral da Cidade do Rio de Janeiro, n. 7, p. 89-104, 2007.

FRANCHETTI, Paulo. Leituras de O Cortiço (notas para um público estrangeiro). Revista Brasileira de Literatura Comparada-ABRALIC. São Paulo, n. 18, p. 87-96, 2011.

. 06/06/2013. Naturalismo no Brasil. Disponível em <http://paulofranchetti.blogspot.com.br/search?q=naturalismo $>$. Acesso em 15/11/2016.

MENDES, Leonardo; VIEIRA, Renata Ferreira. A epopeia da impotência humana: naturalismo, desilusão e banalidade no romance brasileiro do final do século XIX. e-scrita Revista do Curso de Letras da UNIA$B E U$, Nilópolis, v. 3, n. 3, p. 139-152, 2012.

. Introdução. In:

. O Cortiço. São Paulo, Editora Hedra, 2013, p. 9-38.

MÉRIEN, Jean-Ives. Aluisio Azevedo. Vida e Obra (1857-1913). Rio de Janeiro: Fundação Biblioteca Nacional/Garamond, 2013.

REIS, Carlos. Pessoas de livro. Estudos sobre a personagem. Coimbra: Imprensa da Universidade de Coimbra, 2015.

SANT'ANNA, Affonso Romano de. Análise estrutural do romance brasileiro. Petrópolis: Editora Vozes, 1973.

SOUZA, Ricardo Luiz de. O antilusitanismo e a afirmação da nacionalidade. Revista Politeia: História e Sociologia, Vitória da Conquista, v. 5, n. 1, p. 133-151, 2005.

Monica Figueiredo é Mestre e Doutora pela Universidade Federal do Rio de Janeiro (UFRJ) e pós-doutorada pela Universidade de Coimbra (Portugal), onde desenvolveu trabalho de pesquisa sobre a obra de Eça de Queiroz e suas personagens femininas. Atualmente é professora de Literatura Portuguesa da Faculdade de Letras da Universidade Federal do Rio de Janeiro (UFRJ). Assina inúmeros ensaios críticos publicados no Brasil e no exterior, em que investiga não apenas a escola realista portuguesa, mas a relaçáo mantida pela literatura oitocentista com a contemporaneidade. E-mail: mnfigueiredo@hotmail.com

Recebido em: 16/01/2018

Aceito em: 15/07/2018 